\title{
Editorial
}

\section{0 vision: What happens next in education technology research in Australia}

\author{
Kate Thompson \\ Queensland University of Technology, Australia
}

Jason M. Lodge

The University of Queensland, Australia

\begin{abstract}
The COVID-19 pandemic has certainly caused global upheaval in education. The sudden and mass migration of learning online has created challenges and opportunities for educators, educational technologists and researchers of educational technologies and will continue to do so for some time. As we discuss here, there is a likelihood that the COVID-19 pandemic will exacerbate the troubled relationships between policy, research and practice that have existed for the last decade. We focus here on the Australian context as a case in point and argue that changes to the funding of universities and research have contributed to a system in which the available technology has driven educational technology research. We argue that we have a moment to pause and consider how we might work more effectively together to create a better, evidence-informed future for learning with technologies in higher education.
\end{abstract}

Keywords: research funding; policy; evidence-informed practice; COVID-19

\section{Introduction}

The release of this issue of AJET comes with much of 2020 done. So far this year has been one in which decisions about learning and teaching in relation to technology have been made during great uncertainty. The higher education sector is undergoing substantial, rapid change, and as we write this, it is still unknown what the future holds, even what next week will bring. All over the world, in response to the COVID-19 pandemic, economies have slowed or stopped. While the world paused, education underwent an enormous upheaval. Schools and universities (UNESCO, 2020a), Vocational Education and Training (TAFE Queensland, 2020), and professional learning (World Health Organisation, 2020) shifted to online delivery within days and weeks (OECD, 2020b). Educational institutions have had to move quickly rather than strategically plan for changes in teaching environments. Policy and institutional decision-making did not include educational researchers, and practitioners obtained the information they needed for implementation using a range of sources. Alongside the support offered by learning and teaching units within institutions, technology mediated the sharing of practice between educators, crossing institutional and sector boundaries. Examples of tools, tricks, and experiences were shared, using Twitter (e.g. Bayne, 2020; Goodyear, 2020), through online groups and associations (e.g. ASCILITE, 2020), and free access to research (e.g. BJET's special COVID-19 free access to articles about online learning (BJET, 2020). There were also many examples of individuals and companies using the opportunity to gain access to otherwise challenging educational markets.

This editorial is about the future of educational technology research. The COVID-19 pandemic and the associated upheaval in education has raised a complex set of issues with the potential to greatly exacerbate problematic trends that have been apparent for some time internationally. We focus here on the specific example of the Australian context as an example of global trends. We acknowledge that the policy context for funding for educational technology research varies substantially across the region, however it is beyond the scope of this article to include a discussion of all of these. We identify some of the themes that could inform an understanding of what is happening outside Australia.

We argue that changes to the funding of universities and research have contributed to a system in which the available technology has driven educational technology research. Through this example, we will discuss underlying issues in educational technology and the relationship between the research, policy settings and 
the impact of research on practice. The policy context is included because it explains the past in terms of the systematic de-valuation of educational research. In the Australian setting now, there is evidence to support the claim that technology is driving the research agenda. Technology is being implemented by universities, largely driven by policy decisions, and due to the limited availability of funding, we are reacting by researching what we have available. Our contention is that COVID-19 provides an opportunity to rethink some of the relationships between policy, research and practice in order to begin to reverse some of the trends apparent over the last decade. We anticipate that this topic is one about which not everyone will agree. If an editorial in AJET sparks a lively and productive discussion about the future of research in educational technology, particularly at this point in time, then we see that as the best outcome we could imagine. The future, in our opinion, involves working with the end users of our research as we go. The research that this community does is valuable - it should be informing decisions about policy and practice. That this is not happening means that we need to change how we go about doing the research, being leaders.

\section{Education Research 2010-2020}

As is the case in most jurisdictions worldwide, the higher education sector in Australia is a complex space. What follows is a brief description of the organisations that are important in understanding the policy settings in 2020. The higher education sector receives income from the Australian Commonwealth government and from fees paid by international and domestic students and in the last ten years, funding from the Commonwealth government has shifted from supply-driven to demand-driven (Daley et al., 2019). An external regulatory body ensures that there is consistency across all educational offerings at universities, called the Tertiary Education Quality and Standards Agency (TEQSA), established in 2012. A combination of funding decisions and features of the Australian population have resulted in a situation in which domestic enrolments are expected to plateau, and growth for the higher education sector has focused on international students, and the fees they are charged (Norton et al., 2018; Daley et al., 2019). These policy setting have a substantial impact on both research and practice.

The most relevant source of funding for education research is the Australian Research Council (ARC), which is federally funded. Education research does not attract significant proportions of research spending in Australia. Most research expenditure is in scientific and technology disciplines, including medical science (Norton et al., 2018). The Commonwealth government's priority research areas do not include education, and funded education research does not tend to connect to the priority areas (Cutter-Mackenzie \& Renouf, 2017). Following similar models internationally, the assessment of research in higher education institutions is conducted by the ARC and called the Excellence in Research Australia (ERA). Since the first ERA conducted in 2010, Education as an area of research has improved its ranking and is now performing at world standard in the most recent assessment in 2018. Research is classified according to its ultimate aim: Category 1 is basic, foundational research, research in Categories 2-4 involve a partnership with Industry.

Funding for educational research and innovation in higher education has steadily, and at times rapidly, declined in real terms over the last decade (Cutter-Mackenzie \& Renouf, 2017). This trend is true in Australia and is evident in many parts of the world (Marginson, 2016). In 2010 in Australia, the key mechanism for funding innovation in higher education was the Australian Learning and Teaching Council (ALTC). The intention was that quality and innovation in learning and teaching would grow as student numbers increased and technology advanced (Gardner, 2015). In the last decade, funding for the ALTC was cut, the organisation was converted into the Office for Learning and Teaching (OLT), funding for the OLT further decreased, before it was disestablished altogether in 2015 (Kift, 2016). While the Commonwealth Government had promised to establish a replacement institute, this was not implemented (Kift, 2016).

Through its funding, the federal government provided a symbolic focus that reinforced that teaching and learning in universities did matter. The likely abdication of federal involvement in providing the carrot for improving learning and teaching in universities is in sharp relief to the rhetoric of successive governments that rant about the importance and centrality of graduate outcomes and quality. (Nicoll, 2016)

The OLT was an important driver of innovative teaching practice in higher education in Australia. Collaborative research was encouraged, and the results of the research were shared between institutions. 
Without the OLT, there is no dedicated national funding for innovation in teaching in higher education in Australia and the only remaining mechanism for Category 1 educational research funding is the Australian Research Council (ARC) programs.

There was a noted decrease in Category 1 funding (basic, foundational research) in education over the decade, even disregarding the cuts applied to the OLT (Cutter-Mackenzie \& Renouf, 2017). During this time, there have been two significant strategic investments in educational research: the ARC Special Research Initiative for the Science of Learning Research Centre, and the recently funded ARC Centre of Excellence for the Digital Child. ARC Discovery and Linkage projects, and OLT funded projects with education field of research codes totalled approximately \$190 million from 2009-2017 (Cutter-Mackenzie \& Renouf, 2017). In comparison with other disciplines, this translates to a gross underperformance in obtaining national competitive research funding. The major Fellowship and Discovery Project rounds for 2020 yielded only three funded projects in education in total (out of several hundred funded projects), only one in higher education, and none with a strong emphasis on educational technologies. Across all schemes for 2020, education research in the 13 FOR received only $\$ 3.2$ million.

The situation in Australia is therefore that there has been a net decrease in funding for both higher education and for research on innovation in the sector. While this is not a unique situation globally, the Australian setting provides an example of the shift away from research-informed practice and decision making in higher education. This is further exemplified in the position that research and practice have held as the recovery from COVID-19 progresses.

\section{Educational Technology 2010-2020}

The decrease in available funding for research into the use of educational technologies in higher education globally over time is lamentable given the evolution of these technologies and their use. In the last decade, technology drivers (rather than research drivers) have greatly influenced higher education decision making in terms of policy and practice. This has largely been due to the interplay of the funding decisions described above, changes in accessibility and infrastructure, and the popularity of the technologies themselves.

Improvements to processors as well as bandwidth and internet access have supported changes in technology in higher education. Video is more widely used and significant amounts of 'big' educational data can be collected and mined for patterns of student behaviour. In the first half of the decade, Massive Open Online Courses (MOOCs) and flipped learning (in which students do preparatory work outside class, such as, but not exclusively, watching videos to prepare to interact with peers) became popular, and investments in learning analytics were made by universities all over the world. Recent changes in the Australian context include tying funding to student completions and retention and have inspired investment in a range of predictive analytics based on learner behaviour (Norton \& Grattan Institute, 2013).

While the technology drivers were supporting the shift of teaching and learning to online, anywhere and at any time, the policy drivers were ensuring that universities focused investment in the physical learning environments. Within Australia, visa conditions require international students to study on campus for the majority of their classes. Given the importance of international students in university funding models, investments in the physical learning environments were substantial (Norton \& Grattan Institute, 2013). The shift to a more blended approach to higher education, with universities providing physical spaces for students to learn online coincided with increased postgraduate study, and increased work and family responsibilities of students (Norton et al., 2018).

These changes in technology and practice were not informed by research, however they have been the focus of new areas of research, and new approaches to conducting educational research. The research focuses on the potential of these tools to gain insight into the relationships between learning and teaching (e.g. (Brooker et al., 2018; Thompson et al., 2013), examining the impact of MOOCS on accessibility (Park et al., 2019), learning analytics for students (Kitto et al., 2017), and implementation in classrooms (Prieto et al., 2019). Best practice and the influence of video for education is still under discussion (Fyfield et al., 2019). The ways in which learning spaces are designed for, and the links between movement and learning are exciting areas of emerging research (Flynn et al., 2018). Despite the less than ideal policy settings in Australia and internationally, there continues to be significant advancement in technologies and research. There has been 
a widening gulf between the importance and sophistication of these technologies in education and evidence to support practice and policies and associated funding to support them.

\section{Educational Technology in 2020}

The conversation about educational technology in 2020 is clearly going to be about online learning. In midApril, 1.5 billion students were affected by school closures in 195 countries - from pre-primary to higher education (UNESCO, 2020b). Digital technologies have enabled education to continue despite the COVID19 pandemic (OECD, 2020a), at least for those with access to hardware, software, and the internet. Accessibility has been of concern around Australasia (Jalli, 2020) as the global pause exposed the existing digital divide (Marinoni et al., 2020). Due to strategies such as lockdowns in many countries to reduce the spread of COVUD-19, requirements for social and emotional support while learning online have been significant (UNESCO, 2020; OECD, 2020b). Research is already emerging about university strategies to shift to online offerings (e.g. Bao, 2020) and resources are available to support the response to the disruption (Huang et al., 2020; Tertiary Education Quality and Standards Agency, 2020).

Given the misalignment of policy, research and practice, Australia's higher education sector was sorely underprepared to be forced to go fully online with little to no lead time, and Australia is not alone here. Stories are emerging from around the world of the heroic effort many educators have committed to converting their teaching to fully online mode (Marinoni et al., 2020). A distinct lack of funding of research and innovation to inform decisions about effective learning in higher education is one part of the reason why such a huge effort was required. The necessary research was ignored, non-existent or too difficult to translate into practice in a timely manner (as described by Lodge \& Horvath, 2017). Translating research into the use of educational technologies in higher education is essential - for practitioners as well as for policy makers. The remaining void is being readily filled by aspiring international keynoters, technology vendors, or large companies (e.g. Macquarie Group, 2020; Parker, 2020) offering opinions based on their idea of education from a parents' perspective, or the 'silver bullet' to solve all possible problems of online delivery (e.g. Microsoft, n.d.).

In Australia, there has been little evidence to date that educational researchers participated fully in decisionmaking about education or the implementation of online learning in schools. In schools, transitions to and from remote and face-to-face learning were debated in the media (e.g. Carey \& Ilanbey, 2020). Issues regarding teacher safety, accessibility for students, and the importance of early childhood education, as well as final exams for students understandably took precedence. Classroom teachers designed and created online resources for their students with insufficient training and preparation in the tools or the pedagogical approach (e.g. see Baluch, 2020), some in a matter of days. Again, it would seem that the trend towards defunding and devaluing of research into education and educational technologies has played a role here. In Australia, there were substantial, state and institutional decisions made about shifting to learning online (both schools and higher education) and there is considerable expertise that could have been called upon. While the teachers and instructors have done amazing work, we are not in a position to say whether it was successful. Experts could have been supporting decision-makers to choose tools based on research about their affordances, about understanding the considerations when it comes to implementation, workload, designing for online, or accessibility.

\section{0 vision}

Expertise and evidence related to the effective use of educational technologies in higher education do not hold an esteemed place amongst those who make decisions, and the continued decline in funding for research on innovation in higher education reflects this. In 2020 we have observed a fundamental communication breakdown in higher education technology research. Neither the teachers nor the policymakers appear to have used research in educational technology. The ways that we place value on how knowledge is created clearly influence decisions made by individuals, institutions, and now states and countries. The calls for an evidence-base of 'what works' in education is not new (see for example, Foster, 2018). The education research community has some work to do to explain the value of educational research given the common misconception that only research that involves a randomised control trial is rigorous.

Within this context, AJET and similar journals play a crucial role in disseminating evidence based on rigorous research and evaluation of educational technologies with the potential to make a real impact on 
teaching and learning. For example, the inclusion of specific practical implications in AJET abstracts is helpful in providing a foundation for this impact. The high-quality reviews completed by the outstanding pool of AJET reviewers ensures that articles in AJET can be relied upon as a source of sound ideas about the use of educational technologies. Some of the problems the educational technology community is experiencing are due to the lag between when new technologies and approaches emerge and how long it takes for high-quality research and evaluation on these technologies to be published (Lodge \& Horvath, 2017).

In other fields, researchers collaborate in order to define, prioritise and answer the 'big questions' in their field. Collaboration across institutions is necessary to advance educational research:

Within such a culture of increasing research performance measures and metrics, competition is encouraged, rather than collaboration. However, it is collaboration that is most likely to make educational researchers more competitive in the broader Australian research environment. In that sense and as identified in this report there are systemic and cultural issues within the educational research sector itself, which can only be addressed by the sector for the sector. (Cutter-Mackenzie \& Renouf, 2017, p. 6)

To move forward we propose that support is expanded to include the policymakers in the conversation. The shared experience of COVID-19 in 2020 has brought into sharp focus the inadequacies of the current circumstances. What happens next now that practice has been forced to change substantially? How can this learning, teaching and research community use its significant expertise to make a positive, collective, change in the world? Researchers and practitioners are in the best positions to lead, to build the capacity of our colleagues to be part of the rapidly expanding conversation about the use of technologies in education, to use the research to inform practice, to ask questions about what works and why. Researchers, practitioners and policymakers need to work together, acknowledge the value of knowledge created in practice, connect with research priorities, and expound the value of educational technology research in higher education. This could be achieved, for example, by connecting researchers and practitioners through professional bodies, such as ASCILITE, then collectively setting up events and other opportunities to bring the parties together. This approach has been successfully implemented elsewhere, for example, by the organisation Science and Technology Australia (STA; scienceandtechnologyaustralia.org.au) who have been so effective at forging these connections that the Science Meets Parliament event created and run by STA has become an annual event in the Australian national parliamentary calendar.

In the past ten years, educational technology researchers have demonstrated resilience, and determination to understand how people learn, teach and design with and for technology despite substantial devaluing of this expertise by policymakers. The COVID-19 pandemic has raised many questions about what the near and far future of higher education might look like. Universities are adapting structures, funding models and workload allocations (Simons, 2020; Department of Education, 2020), and still we see a collective support for colleagues preparing for the next semester of teaching online. These questions need to be addressed through a concerted effort to bring researchers, practitioners and policymakers together, in much the same way that STA and other organisations have. The risks of not doing so are becoming clear. Unless there is change, the conversation will continue to be driven by economists and self-promoters with a continued decline in the perceived value and utility of research into educational technologies. In a year that seems destined to result in entirely new visions of the future, now is the time to imagine a better one.

\section{Acknowledgements}

The production of AJET is a large team effort. The lead editors Associate Professor Eva Heinrich, Professor Michael Henderson, and Associate Professor Petrea Redmond work with a committed team of associate editors who facilitate the reviews and author revisions of papers: Associate Professor Thomas Donald Cochrane, Associate Professor Linda Corrin, Dr. Eamon Costello, Dr Christopher E Dann, Associate Professor Teresa S Foulger, Associate Professor Paul Gruba, Professor Judi Harris, Dr Henk Huijser, Associate Professor Matthew Kearney, Dr Chien-Ching Lee, Associate Professor Jason M Lodge, Associate Professor Lina Markauskaite, Associate Professor Stephen Marshall, Associate Professor Michael Phillips, Associate Professor Kate Thompson, Professor Joke Voogt. Backing up the editorial team we have two dedicated copyeditors, Kayleen Wood and Antonina Petrolito who work closely with authors to enhance the quality of the articles by ensuring the text is concise, consistent, and accurate. We also need 
to thank our large number of expert reviewers who ensure our articles are of high standard. And finally, thank you to the authors, who offer valuable new understandings in the field of educational technology.

Kate Thompson \& Jason M. Lodge

Associate Editors, Australasian Journal of Education Technology

\section{References}

ASCILITE. (2020, March 30). Register now for the webinar "Crisis and Technology Enhanced Learning: Responses from the ASCILITE Community" to hear about institutional responses and what our communities can do to support one another. 2 April 11am AEDT: https://tinyurl.com/umtdrne. [Tweet with link attached] Twitter. https://twitter.com/ascilite/status/1244416926832447488

Bao, W. (2020). COVID-19 and online teaching in higher education: A case study of Peking University. Human Behavior and Emerging Technologies, 2(2), 113-115. https://doi.org/10.1002/hbe2.191

Baluch, S. (2020, August 12). 'I'm beyond burned out': these teachers reveal the toll coronavirus has taken. SBS Insight. https://www.sbs.com.au/news/insight/i-m-beyond-burned-out-these-teachersreveal-the-toll-coronavirus-has-taken

Bayne, S. (2020, February 14). Twitter colleagues: does anyone have any good examples of teaching online and on-campus students together in a single cohort? Suggestions and links very welcome (yes, it's a tiger-owl...). [Twitter moment] Twitter. https://witter.com/sbayne/status/1228277130586357760?s=20

Birch, D., \& Burnett, B. (2009). Bringing academics on board: Encouraging institution-wide diffusion of e-learning environments. Australasian Journal of Educational Technology, 25(1), 117-134. https://doi.org/10.14742/ajet.1184

BJET. (2020). Covid Special Section. https://onlinelibrary.wiley.com/doi/toc/10.1002/(ISSN)14678535.online.teaching.and.learning.covid19

Brooker, A., Corrin, L., Barba, P. de, Lodge, J., \& Kennedy, G. (2018). A tale of two MOOCs: How student motivation and participation predict learning outcomes in different MOOCs. Australasian Journal of Educational Technology, 34(1), 73-87. https://doi.org/10.14742/ajet.3237

Carey, A. \& Ilanbey, S. (2020, April 7). VCE students short-changed by COVID-19 even if school year extended. The Age. https://www.theage.com.au/national/victoria/vce-students-short-changed-bycovid-19-even-if-school-year-extended-20200407-p54hyh.html

Chakchouk, M., \& Giannini, S. (2020, April 28). Supporting Learning and Knowledge Sharing through Open Educational Resources (OER). https://en.unesco.org/sites/default/files/covid19 joint_oer_call_en.pdf

Cutter-Mackenzie, A., \& Renouf, J.S. (2017). Australian Educational Research Funding Trends Report: A National Stocktake and Review of Category 1 Funding in Education. Canberra: Australian Council of Deans of Education. https://apo.org.au/sites/default/files/resource-files/2017-09/aponid173676.pdf

Daley, J., Duckett, S., Goss, P., Norton, A., Terrill, M., Wood, D., Wood, T., and Coates, B. (2019). Commonwealth Orange Book 2019: Policy priorities for the federal government. Grattan Institute Report No. 2019-03, April 2019, Grattan Institute. https://grattan.edu.au/wpcontent/uploads/2019/04/916-Commonwealth-Orange-Book-2019.pdf

Department of Education, S. and E. (2020). Higher education relief package-Frequently Asked Questions. Department of Education, Skills and Employment; Department of Education, Skills and Employment. https://www.dese.gov.au/covid-19/higher-education/higher-education-faq

Flynn, P., Thompson, K., \& Goodyear, P. (2018). Designing, using and evaluating learning spaces: The generation of actionable knowledge. Australasian Journal of Educational Technology, 34(6), i-v. https://doi.org/10.14742/ajet.5091

Foster, G. (2018). Education Policy Reforms to Boost Productivity in Australia. Australian Economic Review, 51(2), 253-261. https://doi.org/10.1111/1467-8462.12271

Fyfield, M., Henderson, M., Heinrich, E., \& Redmond, P. (2019). Videos in higher education: Making the most of a good thing. Australasian Journal of Educational Technology, 35(5), 1-7. https://doi.org/10.14742/ajet.5930

Goodyear, P. (2020, April 4).Viv - could we ask@SpringerEdu to put the Networked Learning books on open access for a few months? How best to do this@Nick_Melchior_?@NLConf I'd be happy to help - lots of valuable stuff in there for HE colleagues. [Twitter moment] Twitter. https://twitter.com/petergoodyear/status/1246195450090106880?s=20 
Huang, R. H., Liu, D. J., Till, A., Yang, J. F., Wang, H. H., \& et al. (2020). Handbook on Facilitating Flexible Learning During Educational Disruption: The Chinese Experience in Maintaining Undisrupted Learning in COVID-19 Outbreak. Smart Learning Institute of Beijing Normal University. https://iite.unesco.org/wp-content/uploads/2020/03/Handbook-on-Facilitating-FlexibleLearning-in-COVID-19-Outbreak-SLIBNU_V2.0_20200324.pdf

Jalli, N. (2020, July 4). Commentary: E-learning sees no smooth sailing in Malaysia and Indonesia. CNA. https://www.channelnewsasia.com/news/commentary/coronavirus-covid-19-malaysia-indonesiaschool-e-learning-online-12616944

Khalid, M. S., \& Nyvang, T. (2014). A change agent's facilitation process for overcoming the barriers of ICT adoption for educational administration - The case of a rural-Bangladesh vocational institution. Australasian Journal of Educational Technology, 30(5), 547-561. https://doi.org/10.14742/ajet.626

Kift, S. (2016). The decline and demise of the Commonwealth's strategic investment in quality learning and teaching. Student Success, 7(2), 1-9. https://doi.org/10.5204/ssj.v7i2.336

Kitto, K., Lupton, M., Davis, K., \& Waters, Z. (2017). Designing for student-facing learning analytics. Australasian Journal of Educational Technology, 33(5), 152-168. https://doi.org/10.14742/ajet.3607

Macquarie Group. (2020). COVID-19: A defining moment for our education systems? Macquarie Group. Macquarie. https://www.macquarie.com/ph/en/perspectives/covid-19-a-seminal-moment-in-highereducation.html

Marinoni, G., van't Land, H., \& Jensen, T. (2020). The impact of covid-19 on higher education around the world (p. 50). International Association of Universities (IAU). https://www.iauaiu.net/IMG/pdf/iau_covid19 and_he survey_report_final_may_2020.pdf

Nicoll, C. (2016, April 27). Canberra hasn't learned its lesson. The Australian. https://gateway.library.qut.edu.au/login?url=https://search.proquest.com/docview/1784197544?acco untid $=13380$

Norton, A., Cherastidtham, I., \& Grattan Institute. (2018). Mapping Australian higher education 2018. https://grattan.edu.au/report/mapping-australian-higher-education-2018

Norton, A., \& Grattan Institute. (2013). The online evolution: When technology meets tradition in higher education. http://grattan.edu.au/publications/reports/post/the-online-evolution-when-technologymeets-tradition-in-higher-education

OECD. (2020a). Learning remotely when schools close: How well are students and schools prepared? Insights from PISA (OECD Policy Responses to Coronavirus (COVID-19)). OECD. https://read.oecd-ilibrary.org/view/?ref=127_127063-iiwm328658\&title=Learning-remotely-whenschools-close

OECD (2020b). Coronavirus special edition: Back to school. Trends Shaping Education Spotlights, No. 21. OECD Publishing. https://doi.org/10.1787/339780fd-en.

Park, K., So, H.-J., \& Cha, H. (2019). Digital equity and accessible MOOCs: Accessibility evaluations of mobile MOOCs for learners with visual impairments. Australasian Journal of Educational Technology, 35(6), 48-63. https://doi.org/10.14742/ajet.5521

Parker, S. (2020, May 6). COVID19: How the coronavirus could transform higher education - KPMG Australia. KPMG. https://home.kpmg/au/en/home/insights/2020/04/coronavirus-covid-19education-sector-transformation.html

Prieto, L. P., Rodríguez-Triana, M. J., Martínez-Maldonado, R., Dimitriadis, Y., \& Gašević, D. (2019). Orchestrating learning analytics (OrLA): Supporting inter-stakeholder communication about adoption of learning analytics at the classroom level. Australasian Journal of Educational Technology, 35(4), 14-33. https://doi.org/10.14742/ajet.4314

Simons, M. (2020, May 23). The end of the university boom. The Saturday Paper. https://www.thesaturdaypaper.com.au/news/economy/2020/05/23/the-end-the-universityboom/15901560009865

TAFE Queensland. (2020). TAFE Queensland's COVID-19 response-Free micro-credentials and skill sets. https://tafeqld.edu.au/covid-safe

Tertiary Education Quality and Standards Agency. (2020, April 2). Online learning good practice [Text]. Tertiary Education Quality and Standards Agency. https://www.teqsa.gov.au/online-learning-goodpractice

Thompson, K., Ashe, D., Carvalho, L., Goodyear, P., Kelly, N., \& Parisio, M. (2013). Processing and Visualizing Data in Complex Learning Environments. American Behavioral Scientist, 57(10), 14011420. https://doi.org/10.1177/0002764213479368

UNESCO. (2020a, March 24). 1.37 billion students now home as COVID-19 school closures expand, ministers scale up multimedia approaches to ensure learning continuity. UNESCO. 
https://en.unesco.org/news/137-billion-students-now-home-covid-19-school-closures-expandministers-scale-multimedia

UNESCO. (2020b, April 29). 1.3 billion learners are still affected by school or university closures, as educational institutions start reopening around the world, says UNESCO. UNESCO.

https://en.unesco.org/news/13-billion-learners-are-still-affected-school-university-closureseducational-institutions

World Health Organisation. (2020). Coronavirus Disease (COVID-19) Training: Online Training. https://www.who.int/emergencies/diseases/novel-coronavirus-2019/training/online-training

Zamani, B. E., Esfijani, A., \& Damaneh, S. M. A. (2016). Major barriers for participating in online teaching in developing countries from Iranian faculty members' perspectives. Australasian Journal of Educational Technology, 32(3), 38-49. https://doi.org/10.14742/ajet.2678

Corresponding author: Kate Thompson, kate.j.thompson@quut.edu.au

Copyright: Articles published in the Australasian Journal of Educational Technology (AJET) are available under Creative Commons Attribution Non-Commercial No Derivatives Licence (CC BY-NC-ND 4.0). Authors retain copyright in their work and grant AJET right of first publication under CC BY-NC-ND 4.0.

Please cite as: Thompson, K. \& Lodge, J. M. (2020). 2020 vision: What happens next in education technology research in Australia. Australasian Journal of Educational Technology, 36(4), 1-8. https://doi.org/10.14742/ajet.6593 